\title{
PROFESIONALISME GURU DALAM PENINGKATAN MUTU PENDIDIKAN
}

\author{
Muhammad Yunus \\ Sekolah Tinggi Agama Islam (STAI) DDI Pinrang \\ Jl. Andreas Wahani No. 27 \\ Email: staiddipinrang@yahoo.co,id
}

\begin{abstract}
Abstrak:
Tujuan penelitian adalah untuk mengetahui profesionalisme guru dalam peningkatan mutu pendidikan di SDN 65 Katteong Kabupaten Pinrang. Penelitian ini adalah penelitian kualitatif dan instrumen penelitian yang digunakan adalah observasi, wawancara, dan dokumentasi. Adapun teknik analisis datanya adalah teknik analisis deskriptif (non statistik). Hasil penelitian: Pertama, profesionailsme guru dalam peningkatan mutu pendidikan di SDN 65 Katteong Kab. Pinrang dapat dilihat dari 4 (empat) aspek kompetensi, yaitu: kompetensi pedagogik, kompetensi kepribadian, kompetensi social, dan kompetensi profesional. Kedua, Faktor pendukung terdiri dari 2 (dua), yaitu: faktor intern dan faktor ekstern. Sedangkan faktor penghambat, yaitu: banyak guru yang tidak menekuni profesinya secara utuh, adanya perguruan tinggi swasta sebagai pencetak guru yang lulusannya asal jadi, kurangnya motivasi guru dalam meningkatkan kualitas. Ketiga, Strategi guru mengatasi penghambat, yaitu: 1) belajar sendiri di rumah; 2) belajar di perpustakaan; 3) membentuk persatuan pendidik sebidang studi; 4) mengikuti pertemuan ilmiah 5) belajar secara formal di lembaga pendidikan; 6) mengikuti pertemuan organisasi profesi pendidikan; dan 7) ikut kompetisi ilmiah.
\end{abstract}

\begin{abstract}
:
The purpose of this research is to describe the professionalism of teachers in improving the quality of education in SDN 65 Katteong Pinrang. This study is a qualitative research, the data was cellected by observation, interview, and documentation. The data analysis technique was descriptive (non-statistical). The results of this study were: first, the professionalism of teachers in improving the quality of education in SDN 65 Katteong could be seen from four aspects of competence, namely: pedagogic, personal, social, and professional. Second, supporting factors consist of two factors, namely: internal factors and external factors. While the inhibiting factors were: many teachers did not concentrate on their profession, the private colleges did not work properly to produce teachers candidate, this made teachers lack of motivation in improving quality of education. Third, teachers strategies to overcome inhibitors, namely: 1) learning at home; 2) studying in the library; 3) performing union of teachers; 4) involving scientific meetings 5) a formal learning in educational institutions; 6) participating education professional organizations meeting; and 7) involving in follow scientific competition.
\end{abstract}

Kata kunci:

Pendidikan, Profesionalisme, Mutu Pendidikan

PENDIDIKAN merupakan usaha sadar dan terencana untuk mewujudkan suasaan belajar dan proses pembelajaran agar peserta didik secara aktif mengembangkan potensi dirinya untuk memiliki pengendalian, kepribadian, kecerdasan, akhlak mulia, serta keterampilan. Dengan demikian, pendidikan sebagai salah satu instrumen 
utama dalam pengembangan sumber daya manusia yang penyelenggaraannya dapat dilakukan secara demokratis dan berkeadilan serta tidak diskriminatif. Subjek utama dalam proses pengembangan itu dilakukan oleh tenaga kependidikan yang berasal dari anggota masyarakat yang mengabdikan diri dan diangkat untuk menunjang penyelenggaraan pendidikan dengan sasaran untuk mengembangkan kemampuan dan membentuk watak serta peradaban bangsa yang bermartabat dalam rangka mencerdaskan kehidupan bangsa.

Tenaga kependidikan memiliki tanggung jawab untuk mengembangkan tugas itu. Pengertian tenaga kependidikan dapat dilihat dalam ketentuan umum Undangundang Nomor 20 Tahun 2003 tentang Sistem Pendidikan Nasional pasal 1 ayat 5, menjelaskan bahwa tenaga kependidikan adalah anggota masyarakat yang mengabdikan diri dan diangkat untuk menunjang penyelenggaraan pendidikan. ${ }^{1}$

Di samping itu, kedudukan guru sebagai tenaga kependidikan yang profesional bertujuan untuk melaksanakan sistem pendidikan nasional dalam mewujudkan tujuan pendidikan nasional, yaitu berkembangnya potensi peserta didik agar menjadi manusia beriman dan bertaqwa, berilmu, cakap, serta kreatif.

Profesi guru telah hadir cukup lama di negara Indonesia, meskipun hakikat, fungsi, latar tugas, dan kedudukan sosiologisnya telah banyak mengalami perubahan. Sejalan dengan kenyataan itu, keberhasilan pembangunan nasional akan ditentukan oleh keberhasilan dalam mengelola pendidikan nasional dimana di dalamnya guru menempati posisi utama dan penting.

Proses belajar mengajar merupakan inti dari proses pendidikan secara keseluruhan dengan guru sebagai pemegang peran utama. Proses belajar mengajar juga merupakan suatu proses yang mengandung serangkaian perbuatan guru dan siswa atas dasar hubungan timbal balik yang berlangsung dalam situasi edukatif untuk mencapai tujuan tertentu. Interaksi antara guru dan siswa merupakan syarat utama bagi berlangsungnya proses belajar mengajar. ${ }^{2}$ Dalam situasi pembelajaran, gurulah yang memimpin dan bertanggung jawab penuh atas kepemimpinannya yang dilakukan itu. ${ }^{3}$

Kegiatan pembelajaran merupakan kegiatan yang sangat penting dari proses pendidikan. Guru merupakan pelaksana pendidikan yang memiliki peranan penting dalam pencapaian keberhasilan pendidikan. Demikian juga guru memiliki upaya yang sangat penting dalam meningkatkan motivasi belajar siswa.

Tugas utama guru adalah membimbing dan membantu keberhasilan siswa dalam proses belajar mengajar. Profesionalisme seorang guru mutlak diperlukan sebagai bekal dalam mengakses perubahan baik itu metode pembelajaran ataupun kemajuan teknologi yang kesemuanya ditujukan untuk kepentingan proses pembelajaran. Berdasarkan Undang-undang nomor 20 tahun 2003 tentang sitem pendidikan nasional, tugas guru tidak sekedar menyampaikan materi pelajaran kepada siswa, tetapi lebih kepada bagaimana menyiapkan mereka menjadi sumber daya manusia yang terampil dan siap mengakses kemajuan ilmu pengetahuan dan teknologi serta liberalisasi yang terjadi di masa nanti. 
Permasalahan di atas juga menjadi permasalahan yang terjadi di lembaga pendidikan di Pinrang terutama SDN 65 Katteong Kab. Pinrang. Pengalaman peneliti di SDN 65 Katteong menunjukkan adanya keterkaitan antara profesionalisme guru terhadap peningkatan mutu pendidikan. Beberapa pendukung dan penghambat dalam peningkatan profesionalisme guru bisa dilihat dari kompetensi dan kualifikasi guru yang bersangkutan. Guru yang memiliki kompetensi dan kualifikasi bagus akan berdampak pada mutu pengajaran di kelas dan berujung pada peningkatan mutu pendidikan di SDN 65 Katteong Kab. Pinrang.

Bertolak dari landasan berfikir di atas, peneliti dapat mengemukakan problematika yang menjadi pokok pembahasan dalam penelitian ini, sebagai berikut:

1. Bagaimana profesionalisme guru dalam peningkatan mutu pendidikan di SDN 65 Katteong Kab. Pinrang?

2. Bagaimana faktor pendukung dan penghambat profesionalisme guru dalam peningkatan mutu pendidikan di SDN 65 Katteong Kab. Pinrang?

3. Bagaimana strategi guru dalam mengatasi faktor penghambat peningkatan mutu pendidikan di SDN 65 Katteong Kab. Pinrang?

\section{KAJIAN TEORETIS}

\section{Profesionalisme Guru}

Secara etimologi, profesi berasal dari bahasa Inggris profession atau bahasa Latin Profecus, yang artinya mengakui, pengakuan menyatakan mampu, atau ahli dalam melaksanakan pekerjaan tertentu. ${ }^{4}$

Secara terminologi, profesi dapat diartikan sebagai suatu pekerjaan yang mempersyaratkan pendidikan tinggi bagi pelakunya yang ditekankan pada pekerjaan mental, bukan pekerjaan manual. Kemampuan mental yang dimaksudkan di sini adalah adanya persyaratan pengetahuan teoritis sebagai instrumen untuk melakukan perbuatan praktis. ${ }^{5}$

Agama Islam sangat menghargai orang-orang yang berilmu pengetahuan (gu$\mathrm{ru} /$ ulama), sehingga hanya mereka sajalah yang pantas mencapai taraf ketinggian dan keutuhan hidup. Firman Allah swt., dalam QS al-Mujadilah (58): 11:

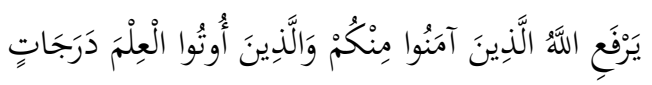

.... Allah akan mengangkat (derajat) orang-orang yang beriman diantara kamu dan orang-orang yang diberi ilmu beberapa derajat ...." 6

Secara umum untuk menjadi guru yang baik dan diperkirakan dapat memenuhi tanggung jawab yang dibebankan kepadanya hendaknya bertakwa kepada Allah swt., berilmu, sehat jasmaniahnya, baik akhlaknya, bertanggung jawab dan berjiwa nasionalis.

Hakikat keprofesionalan jabatan guru tidak akan terwujud hanya dengan mengeluarkan pernyataan bahwa guru adalah jabatan atau pekerjaan profesional. Sebaliknya, status profesional hanya dapat dicapai melalui perjuangan yang berat dan cukup panjang. 
Syafruddin Nurdin mengemukakan bahwa ada enam tahap dalam proses profesionalisasi, yaitu:

1. Bidang layanan ahli "unik" yang diselenggarakan itu harus ditetapkan;

2. Kelompok profesi dan penyelenggara pendidikan prajabatan yang mempersiapkan tenaga guru yang profesional;

3. Adanya mekanisme untuk memberikan pengakuan resmi kepada program pendidikan prajabatan yang memenuhi standar yang telah ditetapkan sebelumnya;

4. Adanya mekanisme untuk memberikan pengakuan resmi kepada lulusan program pendidikan prajabatan yang memiliki kemampuan minimal yang disyaratkan (sertifikasi);

5. Secara perorangan dan secara kelompok, kaum pekerja profesional bertanggung jawab penuh atas segala aspek pelaksanaan tugasnya; dan

6. Kelompok profesional memiliki kode etik yang merupakan dasar untuk melindungi para anggota yang menjunjung tinggi nilai-nilai profesional, disamping merupakan sarana untuk mengambil tindakan penertiban terhadap anggota yang melakukan perbuatan yang tidak sesuai dengan suara dan semangat kode etik itu. ${ }^{7}$

Untuk memenuhi keenam tuntutan tersebut tentu membutuhkan waktu serta melalui proses yang panjang dan berkesinambungan. Dalam upaya peningkatan profesi guru sekurang-kurangnya menghadapi dan memperhitungkan empat faktor, yaitu: 1) ketersediaan dan mutu calon guru, 2) pendidikan prajabatan, 3) mekanisme pembinaan dalam jabatan, dan 4) peranan organisasi profesi. ${ }^{8}$

Sebagai seorang profesional, guru harus memiliki kompetensi keguruan yang memadai. Seorang guru dinyatakan kompeten bila mampu menerapkan sejumlah konsep, asas kerja, dan teknik dalam situasi kerjaanya, mampu mendemonstrasikan keterampilan di lingkungan kerjanya, serta dapat menata seluruh pengalamannya untuk meningkatkan efisiensi kerjanya.

Tuntutan kompetensi seorang guru dapat dirunut dalam penguasaan segi konseptual, penguasaan berbagai keterampilan, dan dalam keseluruhan sikap profesionalnya. Secara singkat dapatlah dikemukakan bahwa seorang guru dinyatakan kompeten jika secara nyata ia mampu menjalankan tugas keguruannya yaitu mampu membelajarkan siswa yang dibimbingnya secara efisien, efektif, dan terpadu. Kompetensi keguruan tidak sekedar menunjuk kuantitas kerja, tetapi lebih-lebih menunjuk atau menuntut kualitas kerja keguruan.

Guru profesional adalah guru yang mengedepankan mutu/kualitas layanan dan produknya, layanan guru harus memenuhi standarisasi kebutuhan masyarakat, bangsa, dan pengguna serta memaksimalkan kemampuan peserta didik berdasar potensi dan kecakapan yang dimiliki masing-masing individu. Untuk menjadi guru yang profesional harus memiliki beberapa kompetensi.

Berbicara tentang kompetensi guru, maka Kuntjojo mengemukakan bahwa kompetensi guru terdiri dari 4 (empat) hal, yaitu:

1. Kompetensi Pedagogik,

2. Kompetensi Kepribadian, 
3. Kompetensi Sosial, dan

4. Kompetensi Profesional. ${ }^{9}$

Hal senada dikemukakan Anik Ghufron bahwa kompetensi yang wajib dimiliki oleh seorang guru, yaitu:

1. Kompetensi kepribadian, yaitu ditunjukkan dengan cirri-ciri berkepribadian yang mantap, berakhlak mulia, arif, dan berwibawa serta menjadi teladan bagi peserta didik.

2. Kompetensi pedagogik, yaitu kemampuan mengelola pembelajaran yang meliputi pemahaman terhadap peserta didik, perancangan, dan pelaksanaan pembelajaran dan pengembangan peserta didik untuk mengaktualisasikan berbagai potensi yang dimiliki.

3. Kompetensi profesional, yaitu kemampuan untuk menguasai materi pembelajaran secara luas dan mendalam yang memungkinkan untuk membimbing peserta didik memenuhi standar kompetensi lulusan yang ditetapkan.

4. Kompetensi sosial, yaitu kemampuan untuk berkomunikasi dan berinteraksi secara efektif dan efisien dengan peserta didik, tenaga kependidikan, orang tua/wali, dan warga masyarakat sekitar. ${ }^{10}$

\section{Peningkatan Mutu Pendidikan}

Mutu dalam pendidikan bukanlah barang akan tetapi layanan, dimana mutu harus dapat memenuhi kebutuhan, harapan, dan keinginan semua pihak/pemakai dengan fokus utamanya terletak pada peserta didik. Mutu pendidikan berkembang seirama dengan tuntutan kebutuhan hasil pendidikan (output) yang berkaitan dengan kemajuan ilmu dan teknologi yangmelekat pada wujud pengembangan kualitas sumber daya manusia. Sebagai suatu lembaga pendidikan formal dalam pelaksanaan sekolah sangat ditekankan adanya peningkatan mutu sebagai jawaban terhadap kebutuhan dan dinamika masyarakat yang sedang berkembang sehingga peningkatan mutu sumber daya manusia dapat diwujudkan melalui pelaksanaan pendidikan.

Secara umum, mutu adalah gambaran dan karakteristik menyeluruh dari barang atau jasa yang menunjukkan kemampuannya dalam memuaskan kebutuhan yang diharapkan atau yang tersirat. Dalam konteks pendidikan, pengertian mutu mencakup input, proses, dan output pendidikan.11

Adapun standar-standar mutu menurut Edward Sallis, yaitu:

1. Standar Produk dan Jasa
a. Kesesuaian dengan spesifikasi
b. Kesesuaian dengan tujuan dan manfaat
c. Tanpa cacat (zero defects)
d. Selalu baik sejak awal

2. Standar Pelanggan

a. Kepuasan pelanggan

b. Memenuhi kebutuhan pelanggan

c. Menyenangkan pelanggan. ${ }^{12}$ 
Sementara Hari Suderadjat mengemukakan bahwa: standar yang dipakai dalam pengukuran quality in fact adalah standar proses dan pelayanan, yaitu yang sesuai dengan spesifikasi dalam perencanaan, cocok dengan tujuan pendidikan, dan time and every time. Standar yang dipakai dalam pengukuran quality in perception adalah standar pelanggan, yaitu kepuasan pelanggan yang dapat meningkatkan permintaan dan harapan pelanggan, yaitu orang tua siswa dan masyarakat lingkungan sekolah. ${ }^{13}$

Pendidikan yang bermutu adalah pendidikan yang mampu menghasilkan lulusan yang memiliki kemampuan atau kompetensi, baik kompetensi akademik maupun kompetensi kejuruan, yang dilandasi oleh kompetensi personal dan sosial, yang secara menyeluruh disebut sebagai kecakapan hidup. Pendidikan kecakapan hidup adalah pendidikan yang bermutu, baik quality in fact maupun quality in perception. Pendidikan yang bermutu adalah pendidikan yang mampu menghasilkan manusia seutuhnya atau manusia dengan pribadi yang integral yang berkemampuan. ${ }^{14}$

Lulusan yang bermutu dapat dicapai dengan proses pembelajaran yang bermutu, yaitu pembelajaran yang berpusat pada siswa, cara belajar siswa aktif dengan menggunakan metoda ilmiah. Pendidikan dasar yang berorientasi pada penguasaan kecakapan Ca-Lis-Tung adalah pendidikan berbasis kompetensi dan berbasis luas yang bermuara pada pemilikan kecakapan hidup. ${ }^{15}$

Mengenai mutu pendidikan dijelaskan dalam Undang-undang Republik Indonesia nomor 20 tahun 2003 tentang Sistem Pendidikan Nasional pasal 1 ayat 17 bahwa standar nasional pendidikan adalah kriteria minimal tentang sistem pendidikan di seluruh wilayah hukum Negara Kesatuan Republik Indonesia. Selanjutnya dalam pasal 35 ayat 1 dijelaskan bahwa standar nasional pendidikan terdiri atas standar isi, proses, kompetensi lulusan, tenaga kependidikan, sarana dan prasarana, pengelolaan, pembiayaan, dan penilaian pendidikan yang harus ditingkatkan secara berencana dan berkala. ${ }^{16}$

\section{METODE PENELITIAN}

\section{Pendekatan dan Jenis Penelitian}

Adapun jenis penelitian yang digunakan adalah kualitatif. Penelitian ini dikonsentrasikan untuk menjelaskan kenyataan-kenyataan yang terjadi di lapangan, serta dapat mengkomunikasikan lebih dari yang dapat dikatakan dengan bahasa yang proporsional.

\section{Sumber Data}

Data merupakan hal yang esensi untuk mengkaji suatu permasalahan, dan data juga diperlukan untuk menjawab masalah penelitian. Maka untuk memperoleh data yang obyektif sesuai dengan sasaran yang menjadi obyek penelitian, data berasal dari:

1. Data Primer, yaitu data yang diperoleh dari sumbernya secara langsung, diamati dan dicatat secara langsung, seperti, wawancara, observasi, dan dokumentasi. 
2. Data Sekunder, yaitu data-data pendukung yang didapat dari buku-buku yang bisa dijadikan referensi, seperti: buku-buku yang berkaitan dengan peran masyarakat, proses belajar mengajar, peningkatan mutu pendidikan, arsip atau dokumen sekolah, media internet dan literatur lainya yang relevan dan berkaitan erat dengan penelitian ini.

\section{Fokus Penelitian}

Dalam penelitian ini, pokok pembahasan ada 3 (tiga), yaitu:

1. Gambaran profesionalisme guru dalam peningkatan mutu pendidikan di SDN 65 Katteong Kab. Pinrang.

2. Faktor pendukung dan penghambat profesionalisme guru dalam peningkatan mutu pendidikan di SDN 65 Katteong Kab. Pinrang.

3. Strategi guru dalam mengatasi faktor penghambat peningkatan mutu pendidikan di SDN 65 Katteong Kab. Pinrang

\section{Teknik dan Istrumen Pengumpulan Data}

Dalam penelitian ini metode pengumpulan data yang digunakan adalah:

1. Metode Dokumentasi; metode ini dilakukan untuk mengumpulkan data yang bersumber dari dokumen yang ada di sekolah ataupun di luar sekolah.

2. Metode Observasi; metode ini dilakukan untuk mengumpulkan fakta, yaitu mengumpulkan pernyataan-pernyataan yang merupakan deskripsi, penggambaran dari kenyataan yang menjadi perhatiannya.

3. Metode Wawancara/Interview; metode ini dilakukan untuk memperoleh keterangan untuk tujuan penelitian dengan cara tanya jawab sambil bertatap muka antara si penanya atau pewawancara dengan si penjawab atau responden.

\section{Teknik Analisis Data}

Proses analisis data yang dilakukan peneliti adalah:

1. Pengumpulan data, dimulai dari berbagai sumber, yaitu dari beberapa informan dan pengamatan langsung yang sudah dituliskan dalam catatan lapangan, transkrip wawancara, dan dokumentasi. Setelah dibaca dan dipelajari serta ditelaah, maka langkah berikutnya mengadakan reduksi data yang dilakukan dengan jalan membuat abstraksi.

2. Proses pemilahan, yang selanjutnya menyusun dalam satu-satuan yang kemudian diintegrasikan pada langkah berikutnya dengan membuat koding.

\section{HASIL PENELITIAN DAN PEMBAHASAN}

\section{Hasil Penelitian}

Guru merupakan profesi profesional di mana ia dituntut untuk berupaya semaksimal mungkin menjalankan profesinya sebaik mungkin. Sebagai seorang profesional, maka tugas guru sebagai pendidik, pengajar, dan pelatih hendaknya dapat berimbas kepada siswanya. Dalam hal ini guru hendaknya dapat meningkatkan terus kinerjanya yang merupakan modal bagi keberhasilan pendidikan. 
Mengingat peran guru yang sangat penting, pemerintah bersama komponen bangsa lainnya telah bersepakat dan hal ini dibuktikan dengan melahirkan Undangundang Republik Indonesia Nomor 20 tahun 2003 tentang Sistem Pendidikan Nasional, Undang-undang Republik Indonesia Nomor 14 tahun 2005 tentang Guru dan Dosen, dan Peraturan pemerintah Nomor 19 tahun 2005 tentang Standar Pendidikan Nasional menyataakan bahwa guru adalah tenaga profesional.

Dalam wawancara Hj. Jasniah, S.Pd selaku kepala SDN 65 Katteong Kab. Pinrang mengemukakan bahwa:

Guru profesional adalah guru yang memiliki kompetensi yang dipersyaratkan untuk melakukan tugas pendidikan dan pengajaran, dalam hal ini: kompetensi pedagogik, kompetensi kepribadian, kompetensi sosial, dan kompetensi profesional. ${ }^{17}$

Berdasarkan pernyataan kepala SDN 65 Katteong Kab.Pinrang di atas, maka dapat disimpulkan bahwa guru-guru di sekolah tersebut dianggap profesional jika telah memenuhi 4 (empat) kompetensi di atas.Oleh karena itu, untuk melihat gambaran tentang profesionalisme guru di SDN 65 Katteong Kab.Pinrang, maka penulis mengadakan observasi terkait dengan hal itu.

\section{Kompetensi Pedagogik}

Upaya memperdalam pemahaman terhadap peserta didik didasari oleh kesadaran bahwa bakat, minat, dan tingkat kemampuan mereka berbeda-beda sehingga layanan secara individual juga berbeda-beda.

Dari pengamatan penulis usaha dalam pemahaman tentang karakteristik peserta didik di SDN 65 Katteong oleh guru berusaha untuk tetap mencapai tujuan pembelajaran yang ada dengan tetap memahami karakteristik peserta didik sebagai mana dikatakan oleh guru di SDN 65 Katteong, sekalipun bahan ajar yang disajikan dalam kelas secara klasikal sama, namun ketika sampai kepada pemahaman individual, guru harus mengetahui tingkat perbedaan individual siswa, sehingga dapat memandu siswa yang percepatan belajarnya terbelakang, sehingga pada akhir pembelajaran memiliki kesetaraan. Pada dasarnya proses pembelajaran ini adalah bagaimana kemampuan pendidik membantu pengembangan seluruh potensi yang dimiliki oleh peserta didik. ${ }^{18}$

Hj. Rastinah, S.PdI. selaku guru PAI SDN 65 Katteong Kab. Pinrang berpandangan bahwa:

Bentuk kompetensi pedagogik yang telah diterapkan di sekolah ini dalam hal pengembangan kurikulum, yaitu: guru dapat menyusun silabus yang sesuai dengan kurikulum, guru merancang rencana pembelajaran yang sesuai dengan silabus untuk membahas materi ajar tertentu, guru mengikuti urutan materi pembelajaran dengan memperhatikan tujuan pembelajaran, dan guru memilih materi pembelajaran yang sesuai dengan tujuan pembelajaran, tepat dan mutakhir, sesuai dengan usia dan tingkat kemampuan belajar peserta didik, dapat dilaksanakan di kelas dan sesuai dengan konteks kehidupan sehari-hari peserta didik. ${ }^{19}$ 
Sementara pengaktualisasian kompetensi pedagogik dalam hal penilaian dan evaluasi, Laintang, S.Pd. selaku guru Penjas SDN 65 Katteong Kab. Pinrang dalam wawancara mengemukakan bahwa:

Gambaran kompetensi pedagogik dalam hal penilaian dan evaluasi yang telah dilaksanakan, diantaranya: guru menyusun alat penilaian yang sesuai dengan tujuan pembelajaran, guru melaksanakan penilaian dengan berbagai teknik dan jenis penilaian, guru menganalisis hasil penilaian untuk mengidentifikasi topik/kompetensi dasar yang sulit, guru memanfaatkan masukan dari peserta didik dan merefleksikannya, dan guru memanfatkan hasil penilaian sebagai bahan penyusunan rancangan pembelajaran yang akan dilakukan selanjutnya. ${ }^{20}$

Arno, S.Pd.I. selaku guru SDN 65 Katteong Kab. Pinrang melalui wawancara kembali mengemukakan bahwa:

Bentuk kompetensi pedagogik dalam hal penguasaan teori belajar dan prinsipprinsip pembelajaran di sekolah ini, yaitu: Guru memberi kesempatan kepada peserta didik untuk menguasai materi pembelajaran sesuai kemampuan belajarnya melalui pengaturan proses pembelajaran dan aktivitas yang bervariasi, guru menggunakan berbagai teknik untuk memotiviasi kemauan belajar peserta didik, guru merencanakan kegiatan pembelajaran yang saling terkait satu sama lain, dengan memperhatikan tujuan pembelajaran maupun proses belajar peserta didik, dan guru memperhatikan respon peserta didik yang belum/kurang memahami materi pembelajaran yang diajarkan dan menggunakannya untuk memperbaiki rancangan pembelajaran berikutnya. ${ }^{21}$

Berdasarkan hasil wawancara tersebut di atas, maka dapat disimpulkan bahwa gambaran profesionalisme guru dalam bidang kompetensi pedagogik yang telah dilaksanakan di sekolah ini terhitung cukup banyak dan berjalan sesuai dengan standar nasional pendidikan. Hal-hal yang telah dilaksanakan tersebut diharapkan senantiasa terus ditingkatkan dan dikembangkan dalam rangka pencapaian peningkatan mutu pendidikan di sekolah ini.

\section{Kompetensi Kepribadian}

Kompetensi kepribadian yaitu; guru memiliki kepribadian yang mantap, stabil, dewasa, arif, dan wibawa, menjadi teladan bagi peserta didik, dan berakhlak mulia.22 Guru sering dianggap sebagai sosok yang memiliki kepribadian ideal. Oleh karena itu, pribadi guru sering dianggap sebagai model atau panutan yang harus digugu dan ditiru.

Sebagai seorang model guru harus memiliki kompetensi yang berhubungan dengan pengembangan kepribadian, diantaranya: (1) kemampuan yang berhubungan dengan pengalaman ajaran agama sesuai dengan keyakinan agama yang dianutnya; (2) kemampuan untuk menghormati dan menghargai antarumat beragama; (3) kemampuan untuk berperilaku sesuai dengan norma, aturan, dan sistem nilai yang berlaku di masyarakat; (4) mengembangkan sifat-sifat terpuji sebagai seorang guru misalnya sopan santun dan tata krama; dan (5) bersikap demokratis dan terbuka terhadap pembaruan dan kritik. 
Melalui wawancara yang dilakukan penulis, Nurjannah, S.Pd. selaku guru SDN 65 Katteong Kab. Pinrang mengemukakan bahwa:

Bentuk kompetensi kepribadian dalam hal pengaktualisasian pribadi yang dewasa dan keteladanan di sekolah, yaitu: guru bertingkah laku sopan dalam berbicara, berpenampilan, dan berbuat terhadap semua peserta didik, orang tua, dan teman sejawat, guru mampu mengelola pembelajaran yang membuktikan bahwa guru dihormati oleh peserta didik, sehingga semua peserta didik selalu memperhatikan guru dan berpartisipasi aktif dalam proses pembelajaran, guru bersikap dewasa dalam menerima masukan dari peserta didik dan memberikan kesempatan kepada peserta didik untuk berpartisipasi dalam proses pembelajaran, serta guru berperilaku baik untuk mencitrakan nama baik sekolah. ${ }^{23}$

Sementara Nurmilawati, S.Pd. selaku guru menyatakan bahwa:

Bentuk kompetensi kepribadian dalam hal etos kerja, tanggung jawab, dan rasa bangga menjadi guru yang dilakukan di sekolah ini, antara lain: guru mengawali dan mengakhiri pembelajaran dengan tepat waktu, guru memenuhi jam mengajar dan dapat melakukan semua kegiatan lain di luar jam mengajar berdasarkan ijin dan persetujuan pengelola sekolah, guru menyelesaikan semua tugas administratif dan non-pembelajaran dengan tepat waktu sesuai standar yang ditetapkan, dan guru memanfaatkan waktu luang selain mengajar untuk kegiatan yang produktif terkait dengan tugasnya. ${ }^{24}$

Sementara Hj. Rusniah mengemukakan bahwa:

Bentuk kompetensi kepribadian dalam hal bertindak sesuai dengan norma agama, hukum, sosial, dan kebudayaan nasional di sekolah ini, antara lain: guru menghargai dan mempromosikan prinsip-prinsip Pancasila sebagai dasar ideologi dan etika bagi semua warga Indonesia, guru mengembangkan kerjasama dan membina kebersamaan dengan teman sejawat tanpa memperhatikan perbedaan yang ada, guru saling menghormati dan menghargai, guru memiliki rasa persatuan dan kesatuan, serta guru mempunyai pandangan yang luas tentang keberagaman bangsa Indonesia. ${ }^{25}$

Dari beberapa pernyatan di atas, maka dapat digambarkan bahwa professionalisme guru dalam kaitannya dengan kompetensi kepribadian yang dilakukan guru di SDN 65 Katteong Kab. Pinrang telah berjalan maksimal untuk peningkatan mutu pendidikan dan pencapaian standar nasional pendidikan.

\section{Kompetensi Sosial}

Kompetensi ini berhubungan dengan kemampuan guru sebagai anggota masyarakat dan sebagai makhluk sosial, yang meliputi: (1) kemampuan untuk berinteraksi dan berkomunikasi dengan teman sejawat untuk meningkatkan kemampuan profesional; (2) kemampuan untuk mengenal dan memahami fungsi-fungsi setiap lembaga kemasyarakatan; dan (3) kemampuan untuk menjalin kerja sama baik secara individual maupun secara kelompok.

Dalam sebuah wawancara, Supratman, A.Ma, selaku guru SDN 65 Katteong mengungkapkan bahwa: 
Pelaksanaan kompetensi sosial di sekolah ini dilaksanakan dalam beberapa cara, di antaranya: bersikap inklusif, bertindak obyektif, serta tidak diskriminatif. Dalam hal ini, guru memperlakukan semua peserta didik secara adil, memberikan perhatian dan bantuan sesuai kebutuhan masing-masing tanpa memperdulikan faktor personal, guru menjaga hubungan baik dan peduli dengan teman sejawat (bersifat inklusif), serta berkontribusi positif terhadap semua diskusi formal dan informal terkait dengan pekerjaannya, serta guru sering berinteraksi dengan peserta didik dan tidak membatasi perhatiannya hanya pada kelompok tertentu. ${ }^{26}$

Sementara Asriana, S.PdI selaku pegawai perpustakaan SDN 65 Katteong Kab. Pinrang mengemukakan bahwa:

Bentuk pelaksanaan profesionalisme guru dalam bidang kompetensi sosial yang dilakukan di sekolah ini, diantaranya: guru menyampaikan informasi tentang kemajuan, kesulitan, dan potensi peserta didik kepada orang tuanya, guru ikut berperan aktif pada kegiatan di luar pembelajaran yang diselenggarakan oleh sekolah dan masyarakat, dan guru memperhatikan sekolah sebagai bagian dari masyarakat, berkomunikasi dengan masyarakat sekitar, serta berperan dalam kegiatan sosial di masyarakat. ${ }^{27}$

Dari hasil wawancara di atas, maka bentuk profesionalisme guru yang berkaitan dengan kompetensi sosial yang telah diterapkan dalam lingkungan sekolah cukup mendukung upaya peningkatan mutu pendidikan di SDN 65 Katteong Kab. Pinrang.

\section{Kompetensi Profesional}

Kompetensi profesional adalah kompetensi atau kemampuan yang berhubungan dengan penyesuaian tugas-tugas keguruan. Kompetensi ini merupakan kompetensi yang sangat penting sebab langsung berhubungan dengan kinerja yang ditampilkan.

Arno, S.PdI selaku guru SDN 65 Katteong Kab. Pinrang mengemukakan bahwa:

Bentuk pelaksanaan kompetensi profesional dalam hal penguasaan materi, struktur, konsep, dan pola pikir keilmuan yang mendukung mata pelajaran yang diampu oleh guru di sekolah ini antara lain: guru melakukan pemetaan standar kompetensi dan kompetensi dasar untuk mata pelajaran yang diampunya, guru menyertakan informasi yang tepat dan mutakhir di dalam perencanaan dan pelaksanaan pembelajaran, serta guru menyusun materi, perencanaan, dan pelaksanaan pembelajaran yang berisi informasi yang tepat, mutakhir, dan yang membantu peserta didik untuk memahami konsep materi pembelajaran. ${ }^{28}$

Sementara Muh. Nasir, S.Pd.I. selaku Sekretaris Komite SDN 65 Katteong Kab. Pinrang memberikan pernyataan bahwa:

Bentuk pelaksanaan kompetensi profesional yang telah dan sedang dilaksanakan di sekolah ini, diantaranya: guru melakukan evaluasi diri secara spesifik, lengkap, dan didukung dengan contoh pengalaman diri sendiri, guru memiliki jurnal pembelajaran, catatan masukan dari teman sejawat atau hasil penilaian proses pembelajaran sebagai bukti yang menggambarkan kinerjanya, dan guru dapat memanfaatkan TIK dalam berkomunikasi dan pelaksanaan Pengembangan Keprofesian Berkelanjutan. ${ }^{29}$ 
Dari hasil wawancara tersebut, maka dapat diketahui tentang gambaran atau bentuk pelaksanaan profesionalisme guru di SDN 65 Katteong Kab. Pinrang yang diharapkan mampu mencapai tujuan pendidikan secara maksimal.

Faktor pendukung dan penghambat profesionalisme guru dalam peningkatan mutu pendidikan di SDN 65 Katteong Kab. Pinrang ada 2 (dua), yaitu faktor dari dalam dan faktor dari luar diri guru itu sendiri. Contohnya: faktor dari dalam, yaitu: latar belakang pendidikan guru, pengalaman mengajar, penguasaan materi, kesadaran untuk meningkatkan kemampuan, lingkungan sekolah yang kondusif, kompetensi manajerial kepala sekolah, kelengkapan sarana dan prasarana, partisipasi masyarakat terutama orang tua/wali murid. ${ }^{30}$

Sedangkan faktor penghambat adalah 1) kualifikasi dan latar belakang pendidikan tidak sesuai dengan bidang tugas, 2) tidak memiliki kompetensi yang diperlukan sesuai bidang tugas, 3) penghasilan tidak ditentukan sesuai dengan prestasi kerja, dan 4) kurangnya kesempatan untuk mengembangkan profesi secara berkelanjutan. ${ }^{31}$

Strategi yang diterapkan di SDN 65 Katteong untuk mengembangkan profesionalisme guru di sekolah ini antara lain;

1. Pembinaan secara rutin sebulan sekali yang berkaitan dengan mental dan karir bagi tenaga pendidik;

2. Menerapkan kelompok diskusi bidang studi di luar jam efektif;

3. Mengirim tenaga pengajar untuk mengikuti workshop/diklat, seminar, lokakarya dan lain-lain yang berkaitan dengan pendidikan;

4. Melengkapi sarana prasarana pendidikan agar proses pendidikan dapat berjalan sesuai harapan;

5. Mengawasi, memantau, dan mengevaluasi kinerja para pengajar dengan memberkan bimbingan;

6. Memberikan reward pada guru yang berprestasi, serta apresiasi positif terhadap prestasi yang diraihnya;

7. Selalu mengadakan supervisi, baik langsung maupun tidak langsung. ${ }^{32}$

\section{Pembahasan Hasil Penelitian}

Pendidikan merupakan masalah yang sangat penting dalam kehidupan berbangsa dan bernegara. Hal ini sesuai dengan tujuan Sistem Pendidikan Nasional yang tertuang dalam UUD Negara Republik Indonesia tahun 1945 pasal 31 ayat 3 menegaskan bahwa:

Pemerintah mengusahakan dan menyelenggarakan satu sistem pendidikan nasional yang meningkatkan keimanan dan ketakwaan serta akhlak mulia dalam rangka mencerdaskan kehidupan bangsa yang diatur dengan undang-undang. ${ }^{33}$

Keberhasilan suatu pendidikan lebih banyak dipengaruhi oleh tenaga pendidik yang dalam hal ini adalah guru. Sehubungan dengan pentingnya peranan seorang guru dalam pendidikan, maka guru harus meningkatkan kompetensinya.

Guru akan selalu menjadi unsur penting yang menentukan berhasil tidaknya pendidikan. Oleh karena itu guru selalu berperan dalam pembentukan sumber daya 
manusia yang potensial di bidang pembangunan bangsa dan negara. Guru adalah orang kedua setelah orang tua yang selalu mendidik dan mengawasi anak untuk menuju cita-cita dan tujuan hidupnya sewaktu akan diserahkan padanya.

Peranan guru dalam proses belajar mengajar sangatlah besar pengaruhnya terhadap perubahan tingkah laku anak didik. Untuk dapat mengubah tingkah laku anak didik sesuai dengan yang diharapkan maka diperlukan seorang guru yang profesional yaitu seorang guru yang mampu menggunakan seluruh komponen pendidikan, sehingga proses pendidikan dapat berjalan dengan baik.

Dalam Undang-undang RI Nomor 20 tahun 2003 tentang Sistem Pendidikan Nasional Bab XI pasal 39 ayat 2 disebutkan bahwa:

Pendidik merupakan tenaga profesional yang bertugas merencanakan dan melaksanakan proses pembelajaran, menilai hasil pembelajaran, melakukan pembimbingan dan pelatihan, serta melakukan penelitian dan pengabdian kepada masyarakat, terutama bagi pendidik pada perguruan tinggi ${ }^{34}$

\section{Hadari Nawawi mengemukakan bahwa:}

Masalah utama pekerjaan profesi adalah implikasi dan konsekuensi jabatan terhadap tugas dan tanggung jawabnya. Tinggi rendahnya pengakuan profesionalisme bergantung pada keahlian dan tingkat pendidikan yang ditempuh. Setiap guru harus memahami fungsinya karena sangat besar pengaruhnya terhadap cara bertindak dan berbuat dalam menunaikan tugasnya sehari-hari di sekolah dan di masyarakat. Pengetahuan dan pemahamnnya tentang kompetensi guru akan mendasari pola kegiatannya dalam menunaikan profesi guru..$^{35}$

Guru sebagai pekerja profesional, sekurang-kurangnya harus menguasai empat kompetensi dengan baik, yaitu: kompetensi pedagogik, kompetensi sosial, kompetensi kepribadian, dan kompetensi profesional.

\section{Kompetensi Pedagogik}

Kompetensi paedagogik merupakan kemampuan yang berkenaan dengan pemahaman peserta didik dan pengelola pembelajaran yang mendidik dan dialogis. Secara substantif kompetensi ini mencakup kemampuan pemahaman terhadap peserta didik, perancangan dan pelaksanaan pembelajaran, evaluasi hasil belajar, dan pengembangan peserta didik untuk mengaktualisasikan berbagai potensi yang dimilikinya.

Kompetensi pedagogik adalah kemampuan mengelola pembelajaran peserta didik yang meliputi pemahaman terhadap peserta didik, perancangan, dan pelaksanaan pembelajaran, evaluasi hasil belajar, dan pengembangan peserta didik untuk mengaktualisasikan beberapa kompeteni yang dimilikinya

Secara rinci elemen kompetensi pedagogik tersebut dapat dijabarkan menjadi sub kompetensi, sebagai berikut:

1. Memahami peserta didik

2. Merancang pembelajaran, termasuk memahami landasan pendidikan untuk kepentingan pembelajaran. 
3. Melaksanakan pembelajaran

4. Merancang dan melaksanakan evaluasi pembelajaran.

5. Mengembangkan peserta didik untuk mengaktualisasikan sebagai potensi yang dimilikinya.

\section{Kompetensi Kepribadian}

Kompetensi kepribadian adalah kemampuan kepribadian yang mantap, stabil, dewasa, arif, dan berwibawa, serta menjadi teladan bagi peserta didik dan berakhak mulia.

Bakat dan minat menjadi guru merupakan faktor penting untuk memperkokoh seseorang memilih profesi guru. Guru adalah teladan bagi anak didik dan masyarakat sekitarnya. Oleh karena itu, kepribadian yang mantap menjadi syarat pokok bagi guru agar tidak mudah terombang-ambing secara psikologis oleh situasi-situasi yang terus berubah secara dinamis (baik positif maupun negatif). Dengan kepribadian seperti ini guru akan mampu tampil berwibawa, arif dalam menyapa, dan mendidik para siswa serta cerdas dalam melayani masyarakat dengan segala perbedaannya.

\section{Kompetensi Sosial}

Guru adalah sosok yang dapat secara luwes berkomunikasi ke segala arah karena bidang tugasnya harus berhubungan dengan siswa, antar guru, dengan atasannya,dan kepada masyarakat di luar sekolah. Kunci keberhasilan guru dalam membina dan membelajarkan siswa maupun anggota masyarakat lainnya, adalah pada kemampuan guru melakukan interaksi sosial ini kepada siswa dan masyarakat lainnya.

Dalam peraturan pemerintah nomor 19 tahun 2005 tentang Standar Nasional Pendidikan dijelaskan bahwa:

Kompetensi sosial yaitu merupakan kemampuan pendidik sebagai bagian dari masyarakat untuk: a) berkomunikasi lisan dan tulisan, b) menggunakan teknologi komunikasi dan informasi secara fungsional, dan c) bergaul secara santun dengan masyarakat sekitar. ${ }^{36}$

\section{Kompetensi Profesional}

Kompetensi profesional adalah kemampuan penguasaan materi pembelajaran secara luas dan mendalam yang memungkinkan membimbing peserta didik memenuhi standar kompetensi yang ditetapkan dalam Standar Nasional Pendidikan. Guru diwajibkan menguasai dengan baik mata pelajaran yang diasuhnya, sejak dari dasardasar keilmuannya sampai dengan bagaimana metode dan teknik untuk mengajarkan serta cara menilai dan mengevaluasi siswa yang mengikuti proses belajar mengajar. Akhir dari proses pembelajaran adalah siswa memiliki standar kompetensi minimal yang harus dikuasai dengan baik sehingga ia dapat melakukan aktivitas sesuai dengan kompetensi tersebut. Guru profesional adalah guru yang menguasai mata pelajaran dengan baik dan mampu membelajarkan siswa secara optimal, menguasai semua kompetensi yang dipersyaratkan bagi seorang guru. 
Menjadi seorang guru bukanlah pekerjaan yang mudah, seperti yang dibayangkan sebagian orang, dengan bermodal penguasaan materi dan menyampaikannya kepada siswa sudah cukup, hal ini belumlah dapat dikategori sebagai guru yang memiliki pekerjaan profesional. Guru yang profesional, mereka harus memiliki berbagai keterampilan, kemampuan khusus, mencintai pekerjaannya, menjaga kode etik guru, dan lain sebagainya.

\section{SIMPULAN}

Berdasarkan hasil penelitian dan pembahasan dalam skripsi ini, maka dapat disimpulkan hal-hal sebagai berikut:

1. Gambaran profesionalisme guru dalam peningkatan mutu pendidikan di SDN 65 Katteong Pinrang dapat dilihat dari 4 (empat) aspek kompetensi, yaitu: a) Kompetensi pedagogik, yaitu: penguasaan karakteristik peserta didik, pengembangan kurikulum, pengembangan potensi peserta didik, penilaian dan evaluasi, penguasaan teori belajar dan prinsip-prinsip pembelajaran, b) Kompetensi kepribadian, yaitu: pengaktualisasian pribadi yang dewasa dan keteladanan, etos kerja, tanggung jawab dan rasa bangga menjadi guru, serta bertindak sesuai dengan norma agama, hukum, sosial, dan kebudayaan nasional, c) Kompetensi sosial, yaitu: dilakukan dengan cara bersikap inklusif, bertindak obyektif, serta tidak diskriminatif, guru menyampaikan informasi tentang kemajuan, kesulitan, dan potensi peserta didik kepada orang tuanya, guru ikut berperan aktif pada kegiatan di luar pembelajaran yang diselenggarakan oleh sekolah dan masyarakat, dan guru memperhatikan sekolah sebagai bagian dari masyarakat, berkomunikasi dengan masyarakat sekitar, serta berperan dalam kegiatan sosial di masyarakat, d) Kompetensi profesional, yaitu: penguasaan materi, struktur, konsep, dan pola pikir keilmuan yang mendukung mata pelajaran yang diampu, guru melakukan evaluasi diri secara spesifik, lengkap, dan didukung dengan contoh pengalaman diri sendiri, guru memiliki jurnal pembelajaran, catatan masukan dari teman sejawat atau hasil penilaian proses pembelajaran.

2. Faktor pendukung dan penghambat profesionalisme guru dalam peningkatan mutu pendidikan di SDN 65 Katteong Kab. Pinrang, yaitu: Faktor pendukung, yaitu: 1) faktor dari dalam, seperti: latar belakang pendidikan guru, pengalaman mengajar, penguasaan materi, kesadaran untuk meningkatkan kemampuan, dan lain-lain, 2) faktor dari luar, seperti: lingkungan sekolah yang kondusif, kompetensi manajerial kepala sekolah, kelengkapan sarana dan prasarana, partisipasi masyarakat terutama orang tua/wali murid, dan lain-lain. Faktor penghambat, antara lain: masih banyak guru yang tidak menekuni profesinya secara utuh, adanya perguruan tinggi swasta sebagai pencetak guru yang lulusannya asal jadi tanpa memperhitungkan outputnya kelak di lapangan, kurangnya motivasi guru dalam meningkatkan kualitas guru, dan lain-lain.

3. Strategi guru dalam mengatasi faktor penghambat peningkatan mutu pendidikan di SDN 65 Katteong Kabupaten Pinrang, yaitu: 1) dengan belajar sendiri di rumah; 
2) belajar di perpustakaan khusus pendidik atau di perpustakaan umum; 3) dengan membentuk persatuan pendidik sebidang studi; 4) mengikuti pertemuan ilmiah, diklat, seminar dan lainnya; 5) belajar secara formal di lembaga pendidikan; 6) mengikuti pertemuan organisasi profesi pendidikan; serta 7) ikut mengambil bagian dalam kompetisi ilmiah.

\section{CATATAN AKHIR:}

1. Abd. Jabbar R. Takdir, Menuju Guru Yang Profesional, Pinrang: Dewan Pendidikan Kab. Pinrang, 2007, h. 1.

2. Moh. Uzer Usman, Menjadi Guru Profesional, Bandung: PT. Remaja Rosdakarya, 2004, h. 1.

3. Suryosubroto, Proses Belajar Mengajar di Sekolah, Jakarta: Rineka Cipta, 1997, h. 3-4.

4. Sudarwan Danim, Inovasi Pendidikan Dalam Upaya Peningkatan Profesionalisme Tenaga Kependidikan, Bandung: Pustaka Setia, 2002, h. 21.

5. Ibid.

6. Departemen Agama RI., Al- Qur'an dan Terjemahnya, cet. III; Bandung: Diponegoro, 2007, h. 543.

7. Syafruddin Nurdin, Guru Profesional dan Implementasi Kurikulum", Jakarta: Quantum Teaching, 2005, h. 19-21.

8. Ibid., h. 23

9. Kuntjojo, Pendidik dan Peserta didik, Kediri: UNP Kediri, 2008, h. 8-12.

10. Anik Ghufron, Kompetensi Guru Sekolah Dasar, Yogyakarta: FIP-UNY, 2008, h. 11 - 14.

11. Artikel Pendidikan, Konsep Dasar MPMBS, (www.dikdasmen.depdiknas.go.id), diakses tanggal 19 oktober 2009.

12. Edward Sallis, Total Quality Management In Education, cetakan ketujuh, Jakarta: IRCiSoD., 2008, h. 57.

13. Hari Suderadjat, Manajemen Peningkatan Mutu Berbasis Sekolah (MPMBS), Bandung: CV. Cipta Cekas Grafika, 2005, h. 2.

14. Ibid., h. $17-18$

15. Ibid. h. 18

16. Undang-undang Republik Indonesia Nomor 20 Tahun 2003 tentang Sistem Pendidikan Nasional

17. Hj. Jasniah, S.Pd., Kepala SDN 65 Katteong Pinrang, Wawancara, Tanggal 29 Mei 2013.

18. Arno, S.Pd.I, Guru SDN 65 Katteong Kab. Pinrang, Wawancara, Tanggal 29 Mei 2013.

19. Hj. Rastinah, S.PdI, Guru PAI SDN 65 Katteong Kab. Pinrang, Wawancara, Tanggal 29 Mei 2013.

20. Laintang, S.Pd, Guru Penjas SDN 65 Katteong Kab. Pinrang, Wawancara, Tanggal 29 Mei 2013.

21. Arno, S.Pd.I, Guru SDN 65 Katteong Kab. Pinrang, Wawancara, Tanggal 29 Mei 2013.

22. Bustami, Loc.cit.

23. Nurjannah, S.Pd, Guru SDN 65 Katteong Kab. Pinrang, Wawancara, Tanggal 29 Mei 2013.

24. Nurmilawati, S.Pd, Guru SDN 65 Katteong Kab. Pinrang, Wawancara, Tanggal 29 Mei 2013.

25. Hj. Rusniah, Guru SDN 65 Katteong Kab. Pinrang, Wawancara, Tanggal 29 Mei 2013.

26. Supratman, A.Ma, Guru SDN 65 Katteong Kab. Pinrang, Wawancara, Tanggal 29 Mei 2013.

27. Asriana, S.PdI, Pegawai Perpustakaan SDN 65 Katteong Kab. Pinrang, Wawancara, Tanggal 29 Mei 2013.

28. Arno, S.PdI, Guru SDN 65 Katteong Kab. Pinrang, Wawancara, Tanggal 29 Mei 2013. 
29. Muh.Nasir, S.PdI, Sekretaris Komite SDN 65 Katteong Kab. Pinrang, Wawancara, Tanggal 29 Mei 2013.

30. Laintang, S.pd., Guru SDN 65 Katteong Kab. Pinrang, Wawancara, Tanggal 29 Mei 2013.

31. Muh. Nasir, S.PdI, Sekretaris Komite SDN 65 Katteong Kab. Pinrang, Wawancara, Tanggal 29 Mei 2013.

32. Hj. Jasniah, S.Pd, Kepala SDN 65 Katteong Kab. Pinrang, Wawancara, Tanggal 29 Mei 2013.

33. Undang-Undang Dasar Negara Republik Indonesia 1945, Amandemen Keempat, Surabaya: Karya Utama, 2002, h. 23.

34. Undang-undang Republik Indonesia Nomor 20 Tahun 2003 Tentang Sistem Pendidikan Nasional

35. Hadari Nawawi, Organisasi Sekolah dan Pengelolaan Kelas, (Jakarta: CV. Haji Agung, 1989), h. 123

36. Peraturan Pemerintah Nomor 19 Tahun 2005 Tentang Standar Nasional Pendidikan

\section{DAFTAR PUSTAKA:}

Danim, Sudarwan, Inovasi Pendidikan dalam Peningkatan Profesionalisme Tenaga kependidikan, Bandung: CV. Pustaka Setia, 2002.

Departemen Agama RI., Al- Qur'an dan Terjemahnya, Cetakan Ketiga, Bandung: Diponegoro, 2007.

Ghufron, Anik, Kompetensi Guru Sekolah Dasar, Yogyakarta: FIP-UNY, 2008.

Kuntjoro, Pendidik dan Peserta Didik, Kediri: UNP Kediri, 2008.

Nawawi, Hadari, Organisasi Sekolah dan Pengelolaan Kelas, Jakarta: CV. Haji Agung, 1989.

Nurdin, Syafruddin, Guru Profesional dan Implementasi Kurikulum, Jakarta: Quantum Teacing, 2005.

Sallis, Edward, Total Quality Management In Education, Cetakan Ketujuh, Jakarta: IRCiSoD, 2008.

Suderadjat, Hari, Manajemen Peningkatan Mutu Berbasis Sekolah (MPMBS), Bandung: CV. Cipta Cekas Grafika, 2005.

Suryosubroto, Proses Belajar Mengajar di Sekolah, Jakarta: Rineka Cipta, 1997.

Takdir, Abd. Jabbar R, Menuju Guru Yang Profesional, Pinrang: Dewan Pendidikan Kab. Pinrang, 2007.

Undang-undang Republik Indonesia Nomor 20 tahun 2003 tentang Sistem Pendidikan Nasional.

Undang-Undang Dasar Negara Republik Indonesia 1945, Amandemen Keempat, Surabaya: Karya Utama.

Usman, Moh. Uzer, Menjadi Guru Profesional, Bandung: PT. Remaja Rosdakarya, 1999. 